\title{
Motherhood and Work: Experience of Women with Established Careers
}

\author{
Gabriela Dal Forno Martins, 1 \\ Orcid.org/0000-0001-6278-7302 \\ Cláudia Luiz Leal ${ }^{2}$ \\ Orcid.org/0000-0002-0676-4496 \\ Beatriz Schmidt ${ }^{3}$ \\ Orcid.org/0000-0003-2907-2297 \\ Cesar Augusto Piccinini ${ }^{3}$ \\ Orcid.org/0000-0002-4313-3247
}

\begin{abstract}
${ }^{1}$ Pontifícia Universidade Católica do Rio Grande do Sul, Porto Alegre, Rio Grande do Sul, Brasil
${ }^{2}$ Clínica Psicológica, Porto Alegre, Rio Grande do Sul, Brasil

${ }^{3}$ Universidade Federal do Rio Grande do Sul, Porto Alegre, Rio Grande do Sul, Brasil
\end{abstract}

\begin{abstract}
We aimed to investigate the experience of primiparous mothers with established careers in relation to motherhood and their work, from pregnancy to the end of maternity leave. Three public employees participated, answering interviews. Qualitative content analysis showed that the experiences of participants were similar in several aspects. Repercussions of work in the experience of motherhood were identified from pregnancy, considering concerns regarding changes and reconciliation of maternal and professional demands. Feelings of insecurity and ambivalence were also present when babies entered daycare center and women returned to work. Since the pregnancy, changes aiming at managing the demands of work and motherhood were identified. Family, social and organizational support received by the participants contributed to this management. Nevertheless, a sense of overload by the accumulation of activities after the baby's entrance in daycare center and the mother's return to work were evidenced, which corroborates literature on the subject.
\end{abstract}

Keywords: Motherhood, work, family relations, dual careers, mother-child relations.

\section{Maternidade e Trabalho: Experiência de Mulheres com Carreiras Profissionais Consolidadas}

\section{Resumo}

O objetivo foi investigar a experiência de mães primíparas, com carreiras profissionais consolidadas, em relação à maternidade e ao seu trabalho, da gestação ao término do período de licença. Três servidoras

* Mailing address: Maestro Mendanha, 91/404 Porto Alegre - RS, Brazil 90620-160. Phone: (51) 9301-9356. E-mail: gabriela.martins@pucrs.br

Support: Manuscript derived from the CRESCI Project, funded by the Brazilian Coordination for the Improvement of Higher Education Personnel - CAPES, as well as the Brazilian National Council for Scientific and Technological Development-CNPq. CAPES and CNPq also supported the authors with scholarship awards. 
públicas federais participaram desse estudo, respondendo entrevistas. A análise de conteúdo qualitativa revelou que as experiências das participantes foram semelhantes em vários aspectos. As repercussões do trabalho na experiência da maternidade foram identificadas desde a gestação, considerando as preocupações frente às mudanças decorrentes da maternidade e à conciliação das demandas profissionais. Sentimentos de insegurança e ambivalência também se fizeram presentes quando do ingresso do bebê na creche e do retorno da mulher ao trabalho. Desde a gestação foram identificados movimentos de adaptação, visando ao gerenciamento das demandas da maternidade e do trabalho. $\mathrm{O}$ apoio familiar, social e organizacional recebido pelas participantes contribuiu para esse gerenciamento. Ainda assim, evidenciou-se sentimento de sobrecarga pelo acúmulo de atividades, mesmo após o ingresso do bebê na creche e o retorno da mãe ao trabalho, o que corrobora a literatura sobre a temática.

Palavras-chave: Maternidade, trabalho, relações familiares, dupla carreira, relações mãe-criança.

\section{Maternidad y Trabajo: Experiencia de Mujeres con Carreras Profesionales Consolidadas}

\section{Resumen}

El objetivo fue investigar la experiencia de madres primíparas, con carreras profesionales consolidadas, en relación a la maternidad y a su trabajo, desde la gestación al término del período de licencia. Tres servidoras públicas federales participaron de este estudio, respondiendo a entrevistas. El análisis de contenido cualitativo reveló que las experiencias de las participantes fueron semejantes en varios aspectos. Repercusiones del trabajo en la experiencia de la maternidad fueron identificados desde la gestación, considerando las preocupaciones frente a los cambios decurrentes de la maternidad y a la conciliación de las demandas profesionales. Sentimientos de inseguridad y ambivalencia también se hicieron presentes en el momento del ingreso del bebé en la guardería y del retorno de la mujer al trabajo. Desde la gestación se identificaron movimientos de adaptación, buscando el gerenciamiento de las demandas de la maternidad y del trabajo. El apoyo familiar, social y organizacional recibido por las participantes contribuyó para este gerenciamiento. Aun así, se evidenció un sentimiento de sobrecarga por la acumulación de actividades, incluso después del ingreso del bebé en la guardería y el retorno de la madre al trabajo, lo que corrobora la literatura sobre la temática.

Palabras clave: Maternidad, trabajo, relaciones familiares, doble carrera, relaciones madre-niño.

The increasing participation of women in the labor market in recent decades has been associated with changes in the family and society (Lopes, Dellazzana-Zanon, \& Boeckel, 2014; Oliveira, Faria, Sarriera, Piccinini, \& Trentini, 2011). Different studies indicate that female employment would be related to later motherhood and a lower number of children (Fiorin, Oliveira, \& Dias, 2014; Gomes, Donelli, Piccinini, \& Lopes, 2008; Shreffler, 2016; Shreffler \& Johnson, 2013). In addition, the fact that women have taken on tasks and entered into contexts that were previously considered to be primarily male, has begun to generate the expectation of greater involvement of the man in the care of the children (Polli, Gabriel, Lopes, \& Piccinini, 2016; Yavorsky, Dush, \& SchoppeSullivan, 2015). However, for most middle-class couples in which both spouses are employed, the move towards a more equitable division in child care is still slow (Pedersen \& Kilzer, 2014; Schoppe-Sullivan \& Mangelsdorf, 2013).

Thus, contemporaneously many women tend to experience pressure due to the demands of motherhood and work (Alstveit, Severinsson, \& Karlsen, 2011). Although employment may increase a woman's sense of self-esteem and confidence, the accumulation of internal and external responsibilities at home also creates negative impacts, such as physical and emotion- 
al overload (Vanalli \& Barham, 2008). Women are usually encouraged to value and invest in both motherhood and work, aspects that have been termed 'competing devotions' (Blair-Loy, 2003).

With regard specifically to the devotion to the children, especially in Western countries, motherhood seems to be permeated by cultural, scientific, professional and legal narratives, which emphasize the need for women to occupy the position of primary caregiver (Sévon, 2012). These narratives are associated with the notion of 'intensive mothering', which, according to Hays (1996), consists of the standardized idea that in order to be a good mother, a woman must give herself fully to the child, invest time, money and put motherhood in the prominent position among all the other dimensions of her life. For mothers who do not feel that they fit into this pattern, it is possible for feelings of guilt, suffering and stress to emerge when this does not occur (Elliott, Powell, \& Brenton, 2015; Murray, 2015). According to Shreffler (2016), the working woman is expected to have fewer children because, in addition to the pressures related to intensive mothering there are also pressures for work productivity and professional success.

Management of the demands of motherhood and work does not always occur calmly (Alstveit et al., 2011). In a review of the literature on the relationship between these two domains, Oliveira et al. (2011) found that reconciling motherhood and work tends to be complex, especially in the early years of the children's lives, as well as in situations where family, social and organizational support is fragile. In these cases, a woman may renounce the professional choices made before becoming a mother, which tends to reduce the female selfesteem and increase family conflicts.

Regarding family support when the woman returns to work after the birth of a child, the role of the father (Sévon, 2012) and of the extended family members, such as grandparents, is highlighted (Vanalli \& Barham, 2008). In relation to social support, although hiring a nanny is the option of some families (Bradt, 1995;
Clarke-Stewart \& Allhusen, 2002; Dimova, Hough, Kyaa, \& Manji, 2015), child care in daycare centers has been gaining importance in a number of countries (Bossi, Soares, Lopes, \& Piccinini, 2014; Miller, Votruba-Drzal, Coley, \& Koury, 2014; Piccinini, Polli, Bortolini, Martins, \& Lopes, 2016). This is also associated with the fact that the start of school life seems to occur progressively earlier (Moran, 2014; Vasconcellos, Seabra, Eisenberg, \& Moreira, 2012). For example, in Brazil, when considering public and private establishments, the number of enrollments in daycare centers practically tripled from 2000 to 2014 (Observatório do Plano Nacional de Educação, 2016). Regarding organizational support, there are indications that flexible working hours and job stability favor management of the demands of motherhood and work (Morais, 2014). In this sense, unlike public servants, self-employed workers may have difficulties, including with regards to maternity leave (Vigoureux, Blondel, Ringa, \& SaurelCubizolles, 2016).

Work seems to interfere with the decision to have a child (Berghammer, 2014; Fiorin et al., 2014). Thus, women with higher levels of education and with established professional careers seem to be more likely to postpone motherhood (Camberis, McMahon, Gibson, \& Boivin, 2014; Lopes et al., 2014). Likewise, they also tend to return and maintain the performance of work activities after becoming mothers (Murray, 2015). In this way, they tend to experience the strains and adjustments necessary to deal with the demands of motherhood and work.

Few studies have investigated this phenomenon (Fiorin, et al., 2014), especially when considering the experience of primiparous women with respect to when they return to work after maternity leave (Alstveit et al., 2011). In addition, as suggested by Liu and Hynes (2012), qualitative studies may be of interest in this area, as they could help to comprehend how decisions about motherhood and work are made during the process of transition to parenthood. From the point of view of the professional practice, such information would contribute to the work of the 
psychologist with women who need to deal with multiple roles (Oliveira et al., 2011), as well as to the formulation of policies to promote the health and well-being of working mothers (Alstveit et al., 2011). Therefore, the aim of the present study was to investigate the experience of primiparous mothers, with established professional careers, regarding motherhood and their work, from the pregnancy to the end of the maternity leave.

\section{Method}

\section{Participants}

Three primiparous mothers (Mother 1: 32 years of age, Mother 2: 36 years, Mother 3: 38 years), with male children, participated in the study. The participants had a medium socioeconomic level, were married to the fathers of the children and resided in the metropolitan area of Porto Alegre, the largest city and capital of the southern-most state in Brazil. All of them had postgraduate degrees, worked full-time in their area of graduation, as federal public servants, holding positions in the same institution, after passing a public employment examination (M1: three years previous, M2: two years previous; M3: five years previous). Mothers with these characteristics were chosen to investigate the experience of motherhood in women whose professional careers were established. Two children were six months of age (Child 1 and Child 2) and the other, five months (Child 3), with them starting daycare at the end of the maternity leave.

The participants were selected from among the members of the research project titled "Impact of the daycare center on socioemotional and cognitive child development: A longitudinal study from the sixth month of the child's life to the end of the preschool years, 2010-2016" - CRESCI (Piccinini, Lopes et al., 2016) ${ }^{1}$. The

The main goal of this study was to analyze the impact of daycare on socioemotional and cognitive development of children during their first four years of life. More specifically, it sought to compare the development of children who attended and did not attend daycare, and relate first three participants that met the inclusion criteria described above and who had all the data collected were selected.

\section{Instruments}

The participants answered the following interviews:

Interview about Motherhood $-6^{\text {th }}$ month (Núcleo de Infância e Família/Projeto CRESCI [NUDIF/CRESCI], 2011a): investigated the experience of motherhood in relation to both the pregnancy and the birth, and in relation to the first 6 months of the child's life.

Interview about the Adjustment of the Child to the Daycare Center - Mother's Version (NUDIF/CRESCI, 2011b): investigated the mother's impressions of how the child was adjusting to the daycare, her feelings about it, and the changes in the family routine.

\section{Data Collection Procedures}

Following the data collection phases of CRESCI Project, the families were contacted via telephone and/or e-mail, at around the sixth month of life of the children, after being indicated by one of the daycare centers where the study was being carried out.

Those who agreed to participate completed the Family Demographic Data Sheet. At this first stage, the mothers completed, individually, the Interview about Motherhood $-6^{\text {th }}$ month. For the purposes of the present study, the mother's feelings and expectations about the child and

this to the quality of family and institutional environments. The study started with 77 families who had a child of, on average, 6 months of age, of whom 29 attended daycare (Daycare Group) and 48 were cared for by the mother or other caregivers, such as a nanny (Non-Daycare Group). Families whose babies attended daycare were recruited at two federal public daycare centers and the other families via announcements in local newspapers or by recommendation of other participants. In addition to the families, the study also counted on the participation of 18 teachers who worked at the two federal public daycare centers. The study involved six time points of data collection: 6,12 , $18,24,36$ and 48 months of the child's life. 
about herself, from pregnancy to the stage of the interview, as well as the aspects related to the mother's work and to the decision regarding daycare arrangements were particularly considered. Approximately 30 days after the child started attending the daycare center, the Interview about the Adjustment of the Child to the Daycare Center - Mother's Version was completed. The interviews were conducted individually, in a room of The Institute of Psychology at The Federal University of Rio Grande do Sul.

\section{Data Analysis Procedures}

The data were analyzed through qualitative content analysis (Laville \& Dionne, 1999). For this, the mothers' responses to the interviews were transcribed and classified into two categories, previously defined from the literature (Alstveit et al., 2011; Oliveira et al., 2011), namely: 1. Repercussions of work on the experience of motherhood: related to factors associated with work that could affect the experience of motherhood, with respect to maternal feelings, childcare and the family relationships; 2 . Management of motherhood and work demands: referring to the effort of mothers to reconcile responsibilities arising from motherhood and work.

Two of the authors of the present study classified all the responses of the participants into the two categories, independently. Afterwards, doubts and disagreements were discussed with a third author, seeking a consensus. For the purposes of analysis, three stages of motherhood were examined in each category: the pregnancy, the maternity leave and one month after the child started attending daycare and the mother's return to work.

\section{Ethical Procedures}

Two local Ethics Committees approved the study (Federal University of Rio Grande do Sul, 2010070; Porto Alegre Hospital of Clinics, 100553). All participants signed the Consent Form.

\section{Results}

The results are presented separately for each category and are illustrated through reports from the participants.

\section{Repercussions of Work on the Experience of Motherhood}

In the gestational period, the mothers highlighted, in a very similar way, feelings of distress and concern about the changes that were occurring and those that would occur, as well as the fear of not being able to reconcile the maternal and professional demands: "At first, I got lost, my god, now what? The first impulse I had was: how am I going to organize everything?" (M1); "My biggest concern as a mother was that I was not sure if I was going to be able to handle the activities [at work], because ... I knew it would continue, even when he came" (M2);

Worry about my schedules, once he got older . . that he would be six months old, that I would have to go back to work. Was I going to be able to reconcile everything and care for him? (M3)

One of the participants mentioned that, due to the intense demands of her work, she imagined that she would not have a child: "I thought I was not going to have a child, you know? I kept thinking about it. Because I work during the day and I work three nights in a school, so..." (M3). Another participant reported that, due to the overload of work during the pregnancy, she had difficulties organizing the home environment and the outfit for the arrival of the child: "Even to buy the layette, I would arrive at the end and still not have the things ready. I always have a lot of activities [at work] and I end up not having time sometimes" (M2).

Despite reports of fears of not being able to reconcile the professional and maternal demands, none of the participants reported having considered the possibility of leaving the job or reducing the amount of hours worked. In this sense, the mothers were very involved with their professional careers: 
My biggest concern was to reconcile these activities, because I knew that I would not be able to completely leave the activities [at work] either. And I didn't want to either, so this was the biggest worry, whether I was going to cope. (M2); I always worked out of the home and, in the early days, I was wondering... Whether I could manage, to be a mother. . . I've always been used to working, would I manage? As if it were a new task, could I succeed, be successful in this task? (M3)

Thus, one of the repercussions of work on the experience of motherhood was the need to select the child's full-time non-maternal care arrangement when the participants had to return to work. For the three mothers, the option to take care of the child in daycare centers seemed to have been well defined already during the maternity leave: "Any other option was out of the question" (M1); "To leave him in the daycare center is part of . . . of the plan, to continue my personal life, as well as being a mother, being a professional" (M2); "So for me, here in Porto Alegre, the ideal is a daycare center or an Early Childhood Education school' (M3). It was noted that two participants, during the pregnancy, when they decided to move to a larger residence, considered the proximity of the place of the new family home to the daycare center the child would attend: "From the beginning, we even thought about choosing the apartment, which would be closer to the daycare center. . . . The reference" (M1); "So we looked for a larger apartment, closer to the daycare center where he would be staying" (M3).

Among the reasons for the option to care for the child in a daycare center, the possibility for socialization of the child was highlighted: "He will have more interaction, many other people, his classmates, so this I think will be the main difference, that he will develop this relational aspect" (M1); "The question of putting him into an activity... something just so it makes him experience being in a group" (M2); "The issue of socialization, which is very important" (M3). The participants also reported insecurity about the possibility of hiring a nanny: "Having to select someone, someone that I imagine would work out, would trust to stay with him at home" (M1); "The main issue is not having a trustworthy person who could stay with him at home" (M2); "Because we're not from here... we're very scared to get someone to stay with him, without knowing them well, you know?" (M3). The intention was also to avoid the involvement and the overload of other family members in the care of the child: "The only other hypothesis would be my mother, who has no way to do this. She has a lot of activities, she still works... and she has my nephew at home to take care of" (M1); or even the unavailability of this form of support: "I do not have any close relatives who could also help" (M2).

Also with regard to the elements of the support network, it was evidenced that the participants had close relationships with some co-workers. Thus, during the maternity leave, two mothers used to take their children to the places where they worked: "He would go with me, he would sleep in the pushchair" (M2); "I went [to the workplace] sometimes, to pass by there, with my colleagues" (M3). In addition, all the participants appeared to be highly motivated to return to work after the end of the maternity leave: "I really like to work, so..." (M1); "The prospect of resuming my life. I think that now I have left the boy calmer so that I can return to my work problems" (M2); "I also miss work. While I enjoy being with him, I miss work. Because it was about six months, right?" (M3).

On the other hand, after the child started attending the daycare center and the mother returned to work feelings of insecurity arose, especially regarding the division of the care of the child with the educators, in an unknown, inaccessible environment:

At first I thought it would be a bit faster, but in fact, the adjustment was not that difficult. Because they had several children starting at the same time, at the times I arrived, the parents were no longer allowed in the classroom, right, so I just let them come and pick him up and they took him. So I did not see 
where he was going and the impression I had when he left was that he was, therefore, always a little distressed, right, that thing of a bit of a sad face. ... In the first week, I was a little bit, like, I could not see how he was received in that environment, and I wished I could see how he was reacting. (M2)

Similarly, another mother appeared to demonstrate ambivalence about the child attending the daycare center and her return to work: "Leaving him in the daycare center was easy, like that, because I always enjoyed working. . . Of course sometimes it causes a, causes a conflict, because I also liked to stay home with him" (M1). The same participant stressed the impact felt when leaving the child in the daycare for the first time:

I think it was even stronger on the first day, the first day was more difficult for me than, than it is now. ... The issue of adjustment is much more for the mother than for the child, right? (M1)

Accordingly, the mother reported her perception about the feelings of the child's father in that period of transition: "[The father] spoke a lot about missing him . . . He reported this, right, he was missing him, wanting to go home, [and the child] was not there" (M1). Similarly, another participant said she missed her son throughout the day after returning to work:

I sometimes miss staying with him, you know? The day I went to get him [at the daycare center] to have a vaccination, I picked him up earlier, so I took him home. It was a good thing because I spent more time with him. (M3)

Taken together, the maternal reports show that the repercussions of work on the experience of motherhood were present since the pregnancy, when the participants reported experiencing worry and concern faced with the changes that were occurring and that were to come, as well as the fear of being unable to reconcile the maternal and professional demands. Another issue that deserved attention was the selection of the care that would be provided for the child when they returned to work, especially the choice of daycare center, which seemed well defined during the maternity leave for all the participants. Throughout this process of transition to motherhood, feelings of insecurity and ambivalence were observed, in view of the child starting to attend the daycare center and the mother returning to work.

\section{Management of Motherhood and Work Demands}

Although the participants reported fears related to not being able to reconcile the maternal and professional demands, adaptive movements in response to the new demands were present from the pregnancy and, in particular, after the birth:

[During the pregnancy] I started to take a few days to dedicate myself to him too. I started to realize that I could do both, but that I need to have some time for him, something that I did not have to have before (M2); I started to organize my life according to him. I think for a long time it will still be like this. Everything I do, how I organize my schedules, is done according to him, right? Until he becomes more independent. (M3)

This need for adjustment was also present during the maternity leave:

It was also like that when he was born. When he was resting, instead of his mother sleeping, his mother would work [laughs]. ... I would do my things, I would see my e-mails and he would play in the pushchair.

(M2)

In addition to the adjustments that she mentioned, the same mother considered that the child adapted to her routine, which suggests a departure from the ideal of intensive mothering: "He would have to get into my routine and he's doing great. I did not change my day to day for him, it was him that adapted" (M2).

Similarly, through the reports of another participant, it was also possible to observe the tendency to move away from the ideal of intensive mothering, from the pregnancy, which can configure a strategy to manage the demands of motherhood and work: "Being a mother, it 
did not seem that I much missed, feeling more feminine, feeling more of a woman, it was not something that hit me like that" (M1). Similar feelings extended over the maternity leave: "I like to let it flow, to see how things are building, rather than try to mold too much, you know? Or it frustrates me thinking that it has to be one way or the other" (M1). This participant made a counterpoint of her own experience with her mother's experience:

Her life [the child's maternal grandmother] was dedicating herself to us. I do not think that's totally right, because she ended up being very constrained with this and I see that, to a certain extent, it was very oppressive for her, you know? An important thing, I think, is to try to limit this. Anyway, from now on I will not be exclusively for him, only for him and for me, he is the meaning of my life. My mother told me a lot about this, that all she wanted was to be a mother, that thing, then she saw that it got hard, that things got difficult. It was not quite the way she expected, it was a lot of work. I think a little bit of that, too, that I had restrictions on the idea of being a mother, of the needs for this, I thought: do I need this to fulfill myself? I don't think so, right? (M1)

At the end of the maternity leave, the participants reported that one of the most important supporting elements, which contributed to their ability to reconcile the maternal and professional demands, was the child's father. Nevertheless, it was evidenced that the main responsible for the care of the child seemed to be the mother:

[The father] wants to be very present, makes a point of being involved in everything, manages to get a break in his schedule to be together. . . In the shifts where there is some flexibility, right, he can, go and get [the child in daycare] (M1);

"[As] I have to work three nights at the school, we had to organize the schedule, his father stays with him. ... His father is also leaving work early sometimes, when he can, to pick him up" (M3);
[The father] makes him sleep when he has to sleep, changes him, does everything. . . . I'm very happy that he's participating a lot. ... There was one day that he had to do everything alone, that I had to travel. I left at dawn, so, it was okay, very messy, like this. He managed to take him to the daycare without shoes [laughs], but that's okay! (M2) Another important element of support that favored the transition of the participants in the return to work was the daycare center: "The welcome was very good. We see that everything is very well structured" (M1); "I can do my things and leave him in an environment that I see that he is, is okay" (M2);

I'm feeling very calm, because I can go to work, I can go back and feel that there is no problem, that nothing bad or difficult is going to happen with him. . . . He's being taken care of there. (M3)

In addition, seeking to better organize herself for the return to work, one of the participants reported that she preferred to initiate the adjustment of the child to the daycare center a little before the official period:

I have chosen to bring it well forward, to start as early as possible. . . I I enjoyed it, I ran about a lot in this period, you know? I ran about to organize my things, and, final$l y$, to organize the return to work, because at home with him, it is impossible to do things, you know, it's a lot, he demands a lot. ... Even to eat lunch, you know, after a long time, like that, to eat well, to stop, calmly. So, for me, it was very good. A period, where, you know, I took a break. To know that he was okay there, that he was safe and that. Then, I got a little time for me. . . For things that for a long time I couldn't, I had time to, to think, to organize, and even to prepare to return [to work]. (M1)

Regarding the daycare center, it was observed that the participants tended to emphasize the positive behavioral changes of the children, one month after starting to attend the institution. It is possible that this was a way for the mothers to better deal with the anxieties 
and worries of that period: "He's a lot more developed. . . . He learned to crawl. He was already dragging himself about, a little before starting. . . . Then he took off, so now" (M1); "He's a little more attentive. There are toys that have several triangles of different sizes, if I put the triangles there, he goes there and wants to take them, so he has that idea" (M2);

He developed an ability different from the way he was. I think they have many toys and they put them on the mattress on the floor; and I think they keep trying to get the toys.

Then, at home he does it too. (M3)

In addition to these behavioral changes, understanding the positive emotional responses of the child also seemed to configure a strategy of the mothers to deal with this period of the child's entry into the daycare and their returning to work: "I see that he likes it, right? He likes to go there, he looks at everybody and laughs at everyone. . . He comes back very happy. When I leave him there, he is happy to go" (M1); "He's calm, we perceive that he's enjoying the daycare, right? We arrive there and he's, he's always playing, happy" (M2);

From the first day he adapted well and now we get there, he goes to the teacher's lap, and he laughs, I already say goodbye to him and when I arrive in the afternoon he recognizes me and he looks very happy, so I'll pick him up. All that surprised me, I hope it will continue like this . . Because I have started working now, I thought he would get upset, but he didn't. (M3)

Also, when they ceased to pay exclusive attention to the child, in order to return to work, the mothers demonstrated that they wanted to compensate for the time they were away from the child. This seemed to be one of the participants' strategies to reconcile the maternal and professional demands, as evidenced in the following reports: "I want to spend most of the weekend with him because I'm at work during the week" (M3);

I've been trying to invest a lot . . I sit with him on the rug, with the toys, seeing what he likes best... This is the most important thing, that he has time at home, where I spend the most time with him (MI); I've been trying to get there at five-thirty ... to get him [at the daycare center], as soon as I can, so I can stay with him a little too, because otherwise he sleeps early, when you realize, we are not going to be interacting anymore. (M2);

On the other hand, despite the effort to manage the demands of motherhood and work, the participants were already quite overloaded, in the first month of the child attending the daycare center and the return to work, due to the accumulation of activities: "I'm feeling overloaded again, full of work to do" (M2);

[I have] to get up early, because I like to bathe him before I take him [to the daycare center]. . . . Also we had to organize ourselves to pick him up. I think the only thing that changed was the rushing (M3); It's very heavy. ... To get out [of the house] with him early, to rush from there [from work] to pick him up. . . . I'm much more tired, than in the period that . . I was at home. (M1)

The same mother also mentioned changes in the family routine at the end of the day, when she and her husband shared the child's care and domestic chores:

We take turns. First I stay with him [the child] a little bit, then he [the father] stays with him. Then we have to go to the supermarket, something like that, he goes. Then he stays with him while I prepare the bottle, bath, these things. And... And that's it, right, its shorter, less time. . . Now it is, life running, working again. (M1)

In summary, with regard to the management of the motherhood and work demands, the mothers' reports revealed that the movements to adapt to the maternal responsibilities were present during pregnancy and maternity leave, as well as after the child started attending the daycare center and the mother returned to work. With regard to the support elements that contributed to this management, the participation of the child's father, the daycare center and the aspects of the work of the participants, among 
them the flexible schedules, stood out. However, even with the family, social and organizational support received, the mothers were quite overloaded with the accumulation of activities. A tendency to emphasize the behavioral changes and positive emotional responses of the child, one month after starting daycare, with little emphasis on the difficulties for the child and for the mother herself in the process was noted. In addition, the participants appeared to seek to move away from the ideal of intensive mothering, which may also be a way of management of motherhood and work demands.

\section{Discussion}

The results of this study suggest that the experiences involving the transition to motherhood of the participants, from pregnancy to the return to work, were quite similar in several aspects. In the gestational period, among the repercussions of work on the experience of motherhood, the fear of not being able to reconcile the maternal and professional demands was observed, reported by all the mothers, which has been discussed in the literature. For example, Blair-Loy (2003) highlighted that professionally successful women tend to believe that it is very difficult to fully and simultaneously invest in motherhood and in the profession. For Shreffler (2016), while on one hand the ideal of intensive mothering seems to pressure women to devote all the time and energy available to child care, on the other hand, labor market norms encourage the same devotion to the career, which can generate feelings of insecurity and ambivalence, faced with these competing devotions.

Similarly, one of the participants in the present study (M3) mentioned that before becoming pregnant she did not imagine that she would have a child due to her intense professional demand. The reports of this mother corroborate a trend that has been identified in several Western countries regarding the association between female participation in the labor market and reduction in the average number of children that a woman has throughout her life (Shreffler \& Johnson, 2013). In Brazil, particularly, census data has shown a reduction from six to two children per woman between 1960 and 2010 (Brazilian Institute of Geography and Statistics [IBGE], 2012).

In a study which included four women without children, aged 35-40 years, of medium socioeconomic level and residents of Porto Alegre, Lopes et al. (2014) identified workrelated justifications for the fact that the participants had not yet become mothers, such as prioritization of seeking job satisfaction and financial independence. It should be noted that the pattern of reproduction seems to be gradually becoming later, particularly for women with higher education (IBGE, 2005; Shreffler, 2016), as was the case for the three participants in the present study, who had their first pregnancy after 30 years of age. Despite the risk factors associated with later motherhood, the literature also shows some advantages, such as greater life experience, maturity and a more consolidated identity, which may contribute to these mothers being more prepared to accept that the child is a separate individual and has its own characteristics (Gomes et al., 2008). These aspects, which are associated with both the motherhood and the childhood emotional development (Gomes et al., 2008), seem to have permeated the experience of the participants in the present study.

Furthermore, even though motherhood was very important to these three mothers, they were also very involved with their work. Thus, despite fears of difficulties in reconciling the maternal and professional demands, none of them reported having thought of leaving their jobs or reducing their working hours. Therefore, it is understood that the work consisted of an important source of personal gratification. It was also highlighted that, due to being federal public servants, in addition to the stability of their workplaces, they were granted six months maternity leave, which is not always provided to women workers in the private sector and helps to reconcile the maternal and professional demands, due to the possibility of longer attention and interaction with the child in the first months of life (Morais, 2014).

In addition to valuing their work activities, two mothers mentioned the importance of the 
interpersonal relationships established with colleagues, so that even during the maternity leave, they used to visit them, taking their children with them. In an ethnographic study involving the monitoring of 16 Chilean women, from the third trimester of pregnancy to the end of the first year of life of the children, Murray (2015) identified that middle-class mothers with higher education tended to return to employment after the sixth month of the child's life. In contrast, in the families with low and medium-low socioeconomic status, the mothers tended to remain the caregivers of their children for longer, moving away from employment and other interpersonal relationships, which constituted a vulnerability factor for these women, with greater risk of developing symptoms of depression, for example.

The results obtained by Murray (2015) also suggest that the selection of non-maternal care for the child, such as care in a daycare center, seems more likely for women happy in their jobs, with relatively high levels of education. Similarly, the three participants of the present study, who had these characteristics, chose to put the child into daycare, which seemed well defined during the period of maternity leave. Undoubtedly the insertion of the child into Early Childhood Education consists of an increasingly frequent non-maternal care arrangement, especially when the woman works full-time (Oliveira et al., 2011) and the family does not have other ways to care for the child (Miller et al., 2014). According to Vanalli and Barham (2008), the migration of people from smaller towns to larger cities has led to a reduction in the number of families living in close geographic proximity; similarly, as many grandparents are also in the labor market, this has reduced their willingness to help in the care of the grandchildren. In this sense, it should be noted that two participants in this study expressed that they could not count on the support from their family members, particularly the maternal grandparents of the children, due to the physical distance or the grandmother's difficult routine.

The three mothers also showed insecurity regarding hiring a nanny. In general, nannies are not specifically trained to perform child care activities (Dimova et al., 2015), nor are they monitored in their functions (Clarke-Stewart \& Allhusen, 2002). Thus, according to Bradt (1995), the feeling of risk may emerge for the family, especially when faced with constant revelations in the media of episodes of neglect and abuse of children in which the nanny was the perpetrator ${ }^{2}$. It is understood that this is one of the factors that makes care by nannies lose ground in some countries, especially in large urban centers, where children tend to be put into daycare earlier and earlier (Moran, 2014).

Another motive highlighted by the three participants regarding the option for daycare was the possibility for the children to socialize. This result corroborates the findings of Piccinini, Polli et al. (2016) in a study that investigated maternal reasons to place the child in the daycare center during the first year of life, in which 69 women from Porto Alegre participated, 26 of whom had children attending daycare centers and 43 whose children were cared for by the mother or by other caregivers. According to the authors, the majority of the mothers (58\%) whose children attended daycare indicated socialization as a reason for choosing this care context, because the child could spend time daily with other people, both children and adults. In the specific case of the three participants in the present study, the focus on socialization was also possibly related to the fact that all the infants were single children. Thus, being aware of this possible benefit of daycare and secure with the choice made seems to have facilitated the return of the mothers to work.

However, feelings of insecurity were reported as having been experienced by the participants, although discreetly, particularly in the early stages of adjustment to the daycare center. Interestingly, this was highlighted with less intensity than expected, based on the literature (Bossi et al., 2014). According to these

2 Through research on websites of large circulation newspapers, it is possible to verify different material published in recent years regarding situations of neglect and abuse against children, in which the perpetrator was supposedly the nanny. In some cases, recordings were made by cameras installed in the residences of the families. 
authors, the child's start at daycare center tends to trigger anxieties and worries, particularly for the mothers, who tend to be very ambivalent about the care the child receives in this context. For the children, this process of adjustment can also be complex, which is evident in manifestations of crying, aggressiveness and recurrent illnesses. Therefore, this transition involves the subjective world of both the child and its parents.

Certainly, the entrance into daycare constitutes an important period not only for the child, but also for the family (Vasconcellos et al., 2012). This is because, in addition to the experience of separation, the relationship with a context outside the home begins, which requires adjustments by the child, as well as other members of the family. In fact, one of the participants stated that the adjustment period seemed more necessary for the mother than for the child. For Bossi et al. (2014) the reactions of the parents at this time may also influence the reactions of the children, and vice versa. Thus, the fact that the three participants of the present study emphasized positive aspects of the daycare, such as the possibility of socialization for the child and the return to work for themselves, may be associated with greater ease in the process of transition to the context of collective care.

With respect to the management of the demands of motherhood and work, adaptive movements in response to the new demands were present since pregnancy. For Camberis et al. (2014), when becoming a mother for the first time, the woman integrates this role into the other roles she already plays. Thus, although pregnancy and the birth of a child represent normative events in the life cycle, these processes are configured as very complex. Obviously, the transition to motherhood influences the identity and well-being of the woman and for Alstveit et al. (2011), when she is a working woman, additional tensions and concerns in relation to how she will reconcile the maternal and professional demands in this period are expected, as evidenced by the participants in the present study. Nevertheless, despite these tensions and concerns, the mothers sought to create alternatives to deal with the new demands. In some cases, these alternatives were practical, to the extent that the demands arose. For example, in the reports about the pregnancy, strategies were highlighted, such as leaving work for some periods for the preparations for the "arrival" of the baby. However, the possibility of being absent from work for some periods, even during pregnancy, is not always accessible to all women. According to Vigoureux et al. (2016), this can be complicated in the case of self-employed women, because their income is integrally linked to the amount they work.

Practical strategies to manage motherhood and work demands were also identified after the child started attending daycare, especially leaving early to get the child, as well as making the most of the time available to interact with the child during the evenings and weekends. Similar strategies were found by Moreira (2008), in a study in which 14 working mothers from Porto Alegre participated. These results suggest that mothers tend to compensate for the little time available with the child by devoting themselves intensely to it when they are together. Thus, it was identified that when they were able to find suitable ways to deal with the new demands, the participants demonstrated a sense of relief of anxiety and reward.

In order to manage the demands of motherhood and work, the three mothers also reported having the support of the child's father. The reports of all of them suggested that the father was involved in the care and that this was appreciated by the mother. According to Berghammer (2014), women with high levels of education may be considered the vanguard in the movement that is occurring in various countries, in the search for greater gender equality. In addition, according to Schoppe-Sullivan and Mangelsdorf (2013), less traditional maternal beliefs about gender roles would be associated with greater encouragement of the father's involvement in the child's care by the mother, which seemed to occur with the participants of the current study. However, it was also evidenced that the mother was the main responsible for this care. This result corroborates the findings of 
Polli et al. (2016), as the father seemed to take on the role of auxiliary and the mother remained the main responsible for the care of the child.

Thus, although there are currently indications of greater male involvement in child care compared to previous generations, this seems to be a slow and gradual process of change (Pedersen \& Kilzer, 2014). According to Yavorsky et al. (2015), although women have entered contexts that were characterized as predominantly male, such as the labor market and higher education, men do not seem to have engaged with the same vigor in typically female activities, such as care of children and household chores. This situation may be related to female overload, which was identified in the reports of the three participants, one month after the child started attending daycare and the mother returned to work.

In the present study, the daycare center also stood out as an important element that favored the transition of the participants to return to work activities. The three mothers were satisfied with the choice of the Early Childhood Education institution, as well as with the attention that the child was receiving in the context of collective care. In addition, another important aspect identified was a tendency to emphasize the behavioral changes and the positive emotional responses of the child, already in its first month in the daycare center, which could have constituted a way of coping better with this period for the participants. There are indications that maternal satisfaction with the child's care can provide greater peace of mind for the women, thus relieving tension and stress, favoring the management of the demands of motherhood and work (Oliveira et al., 2011).

Through their reports, the participants of the present study also seemed to seek to move away from the ideal of intensive mothering. These findings diverged from those obtained by Elliott et al. (2015) in a study in which the interviewees were 16 low-income AfricanAmerican mothers in single-parent families who repeatedly emphasized the importance of sacrificing themselves for their children.
However, it is possible that the sharing of child care between mother and father may be an alternative to reduce the pressure suffered regarding the ideal of intensive mothering (Sévon, 2012). Thus, although the division of care did not necessarily appear to be equal, all the participants in the present study emphasized the paternal involvement with the infant and some flexibility in the family relationship, as, when the mother was not available, the father seemed to take responsibility for the care of the child. This aspect, together with the satisfaction with the daycare center, the characteristics and the appreciation for the professional career, seemed to contribute to the management of motherhood and work demands.

\section{Final Considerations}

The aim of this study was to investigate the experiences of primiparous mothers, with established professional careers, regarding motherhood and their work, from pregnancy to the end of the maternity leave. In general terms, there were reciprocal repercussions between motherhood and work, which affected the management of the demands. This could be identified from pregnancy buttended to accentuate after the birth of the child. It is understood that the family, social and organizational support received by the mothers contributed to this management, potentially constituting protective factors for individual and family development in the cases investigated. Even with indicators of withdrawal from the ideal of intensive mothering, the participants seemed responsive to the needs of their children, which is considered a key aspect for this developmental period, given the state of dependency of the child.

It is recommended that future studies be carried out with larger samples with different characteristics, considering, for example, mothers in single-parent families, with a larger number of children, self-employed or working in the private sector. Likewise, it is suggested that the father be included as a participant, in order to also investigate his experience regarding the 
adjustments between fatherhood and work. It is understood that these studies can contribute to the comprehension of the contemporary family dynamics, in order to offer support for the professional practice and the formulation of public policies.

\section{Authors' Contributions}

Substantial contribution in the concept and design of the study: Gabriela Dal Forno Martins, Cláudia Luiz Leal, Beatriz Schmidt, Cesar Augusto Piccinini.

Contribution to data collection: Gabriela Dal Forno Martins.

Contribution to data analysis and interpretation: Gabriela Dal Forno Martins, Cláudia Luiz Leal, Beatriz Schmidt, Cesar Augusto Piccinini.

Contribution to manuscript preparation: Gabriela Dal Forno Martins, Cláudia Luiz Leal, Beatriz Schmidt, Cesar Augusto Piccinini.

Contribution to critical revision, adding intelectual content: Gabriela Dal Forno Martins e Beatriz Schmidt.

\section{Conflicts of interest}

The authors declare that they have no conflict of interest related to the publication of this manuscript.

\section{References}

Alstveit, M., Severinsson, E., \& Karlsen, B. (2011). Readjusting one's life in the tension inherent in work and motherhood. Journal of Advanced Nursing, 67(10), 2151-2160. doi: 10.1111/j.1365-2648.2011.05660.x

Berghammer, C. (2014). The return of the male breadwinner model? Educational effects on parents' work arrangements in Austria, 19802009. Work, Employment and Society, 28(4), 611-632. doi: 10.1177/0950017013500115

Blair-Loy, M. (2003). Competing devotions: Career and family among women executives. Cambridge, MA: Harvard University Press.

Bossi, T. J., Soares, E., Lopes, R. C. S., \& Piccinini, C. A. (2014). Adaptação à creche e o processo de separação-individuação: Reações dos bebês e sentimentos parentais. Psico, 45(2), 250-260.
Bradt, J. O. (1995). Tornando-se pais: Famílias com filhos pequenos. In B. Carter \& M. McGoldrick (Eds.), As mudanças no ciclo de vida familiar: Uma estrutura para a terapia familiar (pp. 206222). Porto Alegre, RS: Artmed.

Brazilian Institute of Geography and Statistics. (2005). Perfil socioeconômico da maternidade nos extremos do período reprodutivo. Brasília, DF: Author.

Brazilian Institute of Geography and Statistics. (2012). Censo Demográfico 2010: Resultados gerais da amostra. Brasília, DF: Author.

Camberis, A. L., McMahon, C. A., Gibson, F. L., \& Boivin, J. (2014). Age, psychological maturity, and the transition to motherhood among English-speaking Australian women in a metropolitan area. Developmental Psychology, 50(8), 2154-2164. doi: 10.1037/a0037301

Clarke-Stewart, K. A., \& Allhusen, V. D. (2002). Nonparental caregiving. In M. H. Bornstein (Ed.), Handbook of Parenting (pp. 215-252). Mahwah, NJ: Erlbaum.

Dimova, M., Hough, C., Kyaa, K., \& Manji, A. (2015). Intimacy and inequality: Local care chains and paid childcare in Kenya. Feminist Legal Studies, 23(2), 167-179. doi: 10.1007/ s10691-015-9284-6

Elliott, S., Powell, R., \& Brenton, J. (2015). Being a good mom: Low-income, black single mothers negotiate intensive mothering. Journal of Family Issues, 36(3), 351-370. doi: $10.1177 / 0192513 X 13490279$

Fiorin, P. C., Oliveira, C. T., \& Dias, A. C. G. (2014). Percepções de mulheres sobre a relação entre trabalho e maternidade. Revista Brasileira de Orientação Profissional, 15(1), 25-35.

Gomes, A. G., Donelli, T. M. S., Piccinini, C. A., \& Lopes, R. C. S. (2008). Maternidade em idade avançada: Aspectos teóricos e empíricos. Interação em Psicologia, 12(1), 99-106.

Hays, S. (1996). The cultural contradictions of motherhood. New Haven, CT: Yale University Press.

Laville, C., \& Dionne, J. (1999). A construção do saber: Manual de metodologia da pesquisa em ciências humanas. Porto Alegre, RS: Artmed.

Liu, S., \& Hynes, K. (2012). Are difficulties balancing work and family associated with subsequent fertility? Family Relations, 61, 16-30. doi: 10.1111/j.1741-3729.2011.00677.x 
Lopes, M. N., Dellazzana-Zanon, L. L., \& Boeckel, M. G. (2014). A multiplicidade de papéis da mulher contemporânea e a maternidade tardia. Temas em Psicologia, 22(4), 917-928. doi: 10.9788/TP2014.4-18

Miller, P., Votruba-Drzal, E., Coley, R. L., \& Koury, A. (2014). Immigrant families' use of early childcare: Predictors of care type. Early Childhood Research Quarterly, 29, 484-498. doi: 10.1016/j.ecresq.2014.05.011

Morais, A. M. B. (2014). Licença-maternidade: Vivências de servidoras públicas de Fortaleza no cuidado com os filhos menores de dois anos (Master's thesis). Retrieved from http://repositorio.ufc.br/handle/riufc/13586

Moran, K. K. (2014). Early childcare settings and the parental enrollment process: Insights from the maternal primary caregivers of children attending high-poverty urban childcare centers (Doctoral dissertation). Retrieved from http:// cdm16002.contentdm.oclc.org/cdm/ref/ collection/p245801 coll10/id/272591

Moreira, L. E. (2008). “Vida de equilibrista?": Mães trabalhadoras em diferentes contextos sociais (Doctoral dissertation). Retrieved from http:// www.lume.ufrgs.br/handle/10183/13413

Murray, M. (2015). Back to work? Childcare negotiations and intensive mothering in Santiago de Chile. Journal of Family Issues, 36(9), 11711191.

Núcleo de Infância e Família/Projeto CRESCI. (2011a). Entrevista sobre a maternidade $-6^{\circ}$ mês [Interview about motherhood $-6^{\text {th }}$ month]. Porto Alegre, RS: Instituto de Psicologia, Universidade Federal do Rio Grande do Sul.

Núcleo de Infância e Família/Projeto CRESCI. (2011b). Entrevista sobre a adaptação do bebê à creche - Versão mãe [Interview about the adjustment of the child to the daycare center Mother's version]. Porto Alegre, RS: Instituto de Psicologia, Universidade Federal do Rio Grande do Sul.

Observatório do Plano Nacional de Educação. (2016). Metas para Educação Infantil. Retrived from http://www.observatoriodopne.org.br/metas-pne/1-educacao-infantil

Oliveira, S. C., Faria, E. R., Sarriera, J. C., Piccinini, C. A., \& Trentini, C M. (2011). Maternidade e trabalho: Uma revisão da literatura. Interamerican Journal of Psychology, 45(2), 271-280.
Pedersen, D. E., \& Kilzer, G. (2014). Work-to-family conflict and the maternal gatekeeping of dualearner mothers with young children. Journal of Family and Economic Issues, 35, 251-262. doi: 10.1007/s10834-013-9370-3

Piccinini, C. A., Lopes, R. C., Becker, S. M., Martins, G. F., Gabriel, M. G., Polli, R. G., \& Tudge, J. (2016). Impacto da creche no desenvolvimento socioemocional e cognitivo infantil: Estudo longitudinal do sexto mês de vida do bebê ao final dos anos pré-escolares, 2010-2016 - CRESCI [Impact of the daycare center on socioemotional and cognitive child development: A longitudinal study from the sixth month of the child's life to the end of the preschool year]. Unpublished research project, Instituto de Psicologia, Universidade Federal do Rio Grande do Sul, Porto Alegre, RS, Brazil.

Piccinini, C. A., Polli, R. G., Bortolini, M., Martins, G. D., \& Lopes, R. C. S. (2016). Razões maternas para colocar ou não o bebê na creche. Arquivos Brasileiros de Psicologia, 68(3), 59-74.

Polli, R. G., Gabriel, M. R., Lopes, R. C. S., \& Piccinini, C. A. (2016). Envolvimento paterno aos 12 meses de vida do bebê. Psico, 47(3), 198208.

Schoppe-Sullivan, S. J., \& Mangelsdorf, S. C. (2013). Parent characteristics and early coparenting behavior at the transition to parenthood. Social Development, 22(2), 363-383.

Sévon, E. (2012). 'My life has changed, but his life hasn't': Making sense of the gendering of parenthood during the transition to motherhood. Feminism \& Psychology, 22(1), 60-80.

Shreffler, K. M. (2016). Contextual understanding of lower fertility among US women in professional occupations. Journal of Family Issues. doi: $0192513 X 16634765$.

Shreffler, K. M., \& Johnson, D. R. (2013). Fertility intentions, career considerations and subsequent births: The moderating effects of women's work hours. Journal of Family and Economic Issues, 34(3), 285-295. doi: 10.1007/s10834-0129331-2

Vanalli, A. C. G., \& Barham, E. J. (2008). A demanda para políticas públicas adicionais para trabalhadores com filhos pequenos: $\mathrm{O}$ caso de professoras. Temas em Psicologia, 16(2), 231-241.

Vasconcellos, V. M. R., Seabra, K. C., Eisenberg, Z. W., \& Moreira, A. R. C. P. (2012). O lugar da 
creche nos debates sobre parentalidade e coparentalidade. In C. A. Piccinini \& P. Alvarenga (Eds.), Maternidade e paternidade: A parentalidade em diferentes contextos (pp. 341-365). São Paulo, SP: Casa do Psicólogo.

Vigoureux, S., Blondel, B., Ringa, V., \& Saurel-Cubizolles, M. J. (2016). Who are the women who work in their last month of pregnancy? Social and occupational characteristics and birth outcomes of women working until the last month of pregnancy in France. Maternal and Child Health Journal, 20(9), 1774-1779. doi: 10.1007/ s10995-016-2009-x
Yavorsky, J. E., Dush, C. M. K., \& Schoppe-Sullivan, S. J. (2015). The production of inequality: The gender division of labor across the transition to parenthood. Journal of Marriage and Family, 77(3), 662-679. doi: 10.1111/jomf.12189

Received: $31 / 10 / 2016$

$1^{\text {st }}$ revision: $17 / 11 / 2017$

Accepted: 21/03/2018 distribution, and reproduction in any medium, provided you give appropriate credit to the original author(s) and the source, provide a link to the Creative Commons license, and indicate if changes were made. 